\title{
Finite Element Implementation of Multi-Pass Fillet Weld with Phase Changes
}

Pavol Novák, Jozef Meško, Milan Žmindák

University of Žilina, Faculty of Mechanical Engineering, Department of Applied Mechanics, Univerzitná 1, 01026 Žilina. Milan.zmindak@gmail.com

First, in this paper, a brief review of theoretical aspects of weld simulation and residual stress modelling using the finite element method (FEM) is presented. Thermo-elastic-plastic formulations using a von Mises yield criterion with nonlinear isotropic hardening has been employed. Residual stresses obtained from the analysis have been shown. The commercial FEM code ANSYS and a user created code were used for uncoupled thermalmechanical analysis. Second, the aim of this paper is to compare ANSYS capabilities extended by authors to model weld phenomena versus well known SYSWELD code. Element birth and death FEM technique was used to simulate the weld metal added to base metal due the welding process and to reset plastic history for molten portion of material. Goldak's double ellipsoid heat source was used to model welding heat source. The Leblond's model was used to simulate ferritic and bainitic phase transformations and Koistinen - Marburger model was used to simulate martensitic transformation.

Keywords: phase changes, metallurgical transformations, residual stresses, finite element method.

\section{Acknowledgement}

The work has been supported by the grant project KEGA No. 054 ŽU-4-2012 and VEGA 1/1259/12.

\section{References}

[1] GÜR, C. H., PAN, J., (2009).Hanbook of thermal process modelling of steel, Taylor \& Francis Group, 2009.

[2] SÁGA, M., KOPAS, P., VAS̆KO, M. (2010). Some Computational Aspects of Vehicle Shell Frames Optimization Subjected to Fatigue Life. Communications, Vol. 12, No. 4, pp. 73-79.

[3] MEŠKO, J., FABIAN, P., HOPKO, A., KOŇÁR, R. (2011). Shape of heat source in simulation program SYSWELD using different types of gases and welding methods. Strojírenská technologie, Vol. XVI, No. 5, pp. 6-11.

[4] CHOTEBORSKÝ, R., HRABĚ, P., NAVRÁTILOVÁ, M. (2009). Influence of Welding parameters on geometry of weld deposite bead. In: Proceedings of the International Scientific Conference, (M. Brožek, (Ed)), pp. 91-95, Czech University of Life Science, Prague.

[5] ŽMINDÁK, M., NOVÁK, P., MEŠKO, J. (2010), Numerical simulation of arc welding processes with metallurgical transformations, Metallurgy, Vol. 49, No.2, pp. 595-599.

[6] SATTARI-FAR. I., FARAHI, M.R. (2009). Effect of the weld groove shape and pass number on residual stress in butt-welded pipes, International journal of Pressure vessels and Piping Vol. 86, pp. 723-731.

[7] NOVÁK, P. (2010). Analysis of Residual stresses in welding joints, Ph.D. thesis, University of Žilina, Žilina, (in Slovak).

[8] KOVANDA, K., HOLUB, L., KOLǍ̌ÍK, L., KOLǍ̌ÍKOVÁ, M., VONDROUŠ, P., (2012). Experimental verification of FEM Simulation of GMAW bead on plate welding, Manufacturing Technology Vol.12, No. 12, pp. 30-33. 